JOURNAL OF ISLAMIC EDUCATION

Vol. 6 No. 2 November 2021

P-ISSN 2503-5363; E-ISSN 2528-0465

http://www.ejournal.stitmuhbangil.ac.id/index.php/jie

\title{
Implementasi Teknik Penilaian Blended Learning Pada Keterampilan Pembelajaran Fiqih Masa Pandemi Covid-19
}

\author{
*Ahmad Khoirun Nasir ${ }^{1}$, Andi Prastowo ${ }^{2}$ \\ ${ }_{1,2}$ (Universitas Islam Negeri (UIN) Sunan Kali Jaga, Jl. Laksda Adisucipto, DIY) \\ *20204011026@student.uin-suka.ac.id
}

\begin{tabular}{|c|c|}
\hline Informasi Artikel & Abstract \\
\hline $\begin{array}{l}\text { Received: } \\
1 \text { Juli } 2021\end{array}$ & $\begin{array}{l}\text { The purpose of this study was to determine the } \\
\text { application of the skill aspect of blended learning } \\
\text { assessment techniques in fiqh learning during the }\end{array}$ \\
\hline $\begin{array}{l}\text { Accepted: } \\
12 \text { Agustus } 2021\end{array}$ & $\begin{array}{l}\text { covid-19 pandemic at Madrasah Ibtidaiyah Ngabar } \\
\text { Ponorogo. The method used in this study uses a } \\
\text { qualitative approach. The data collection using }\end{array}$ \\
\hline $\begin{array}{l}\text { Published: } \\
8 \text { November } 2021\end{array}$ & $\begin{array}{l}\text { interview and documentation techniques. The } \\
\text { results of this study indicate that the learning } \\
\text { concept used in Madrasah Ibtidaiyah Ngabar }\end{array}$ \\
\hline $\begin{array}{l}\text { Keywords: } \\
\text { Blended Learning, Skills } \\
\text { Assessment Techniques, } \\
\text { Fiqh, Covid-19 Pandemic, } \\
\text { Madrasah. }\end{array}$ & $\begin{array}{l}\text { Ponorogo uses a combination of two learning } \\
\text { systems, namely online and offline or blended } \\
\text { learning. The technique for assessing the skill } \\
\text { aspect of blended learning uses performance } \\
\text { appraisal techniques or practices and products in } \\
\text { fiqih learning during the covid-19 pandemic and in } \\
\text { its implementation there are advantages and } \\
\text { disadvantages. The conclusion of this study is } \\
\text { that the learning of fiqh at Madrasah Ibtidaiyah } \\
\text { Ngabar Ponorogo applies a blended learning } \\
\text { model with techniques for assessing aspects of } \\
\text { performance skills or practices and products that } \\
\text { are going well even though there are } \\
\text { shortcomings in implementation in the field during } \\
\text { the covid-19 pandemic. }\end{array}$ \\
\hline
\end{tabular}

\section{PENDAhULUAN}

Corona Virus Disease (Covid 19) merupakan virus yang pertama kali di temukan di kota Wuhan China (Wachyudi, 2020). Perubahan yang tampak dari adanya virus ini mempengaruhi kepada dunia pendidikan. Diantaranya, 
Kebijakan pemerintah mengenai pelaksanaan pembelajaran yang menerapkan sistem daring atau pembelajaran jarak jauh dan pembelajaran tatap muka yang dikenal dengan sistem luring. Kombinasi antara Kedua sistem tersebut dapat dikenal dengan istilah Blended Learning (Nasution, Jalinus, \& Syahril, 2019).

Pelaksanaan proses pembelajaran dengan kedua gabungan sistem tersebut juga tidak mudah bagi guru jika diterapkan di masa pandemi. Sebab perlu adanya berbagai pertimbangan di antara nya jarak tempat tinggal siswa, fasilitas alat daring atau smartphone siswa yang digunakan dalam kegiatan pembelajaran ditambah perlu adanya teknik penilaian yang tepat dalam mengukur pencapaiain pembelajaran di masa pandemi (Purwanto, 2011).

Pelaksanaan pembelajaran pendidikan agama Islam tidak hanya memuat teori atau materi keagamaan saja, melainkan juga ada praktek dan penugasan untuk mengukur pemahaman siswa terhadap teori atau materi yang disampaiakan guru sebagai implementasi penilaian kompetensi Inti dari aspek ketrampilan (Ikhwan, 2013). Sebagaimana di jelaskan di dalam PERMENDIKBUD Tentang Standar Penilaian Pendidikan bahwa penilaian ketrampilan merupakan sebuah kegiatan untuk mengukur kemampuan peserta didik menerapkan pengetahuan dalam melalukan tugas tertentu (Menteri Pendidikan dan Kebudayaan RI, 2016).

Dampak pandemi covid-19, sistem pembelajaran yang digunakan perpengaruh dalam pemilihan teknik penilaian guru khususnya pada aspek keterampilan (Ikhwan, Anwar, \& Mahmudah, 2021). Berdasarkan data wawancara dengan ustdz Ahmad Daroini, S.Pd selaku pengampu materi fiqih menyampaikan di Madrasah Ibtidaiyah Ngabar ponorogo selama pandemi covid-19 pada pelajaran fiqih menerapkan dua sistem pembelajaran yaitu pembelajaran daring dan luring atau yang dikenal dengan istilah blended learning. Hal ini menujukan dalam menjalankan sebuah penilaian keterampilan guru harus kreatif dan adil dalam menentukan teknik penilaian yang digunakan sebab berbicara aspek keterampilan merupakan salah Kompetensi inti yang wajib dinilai ditambah kondisi pandemi covid-19. Disisi lain dampak penilaian 
aspek keterampilan menurut cahyono dan aim abdul dalam jurnalnya yang berjudul "Pengaruh Penilaian keterampilan mata pelajaran PPKN dalam Kurikulum 2013 terhadap pembinaan tanggungjawab warga negara" (Karim \& Abdul, 2015), bahwa melalui penilaian keterampilan peserta didik akan memiliki tanggungjawab yang tinggi dalam menyelesaikan tugasnya. Berdasarkan permasalah diatas, Maka penulis tertarik meniliti tentang implementasi teknik penilaian blended learning pada keterampilan pembelajaran fiqih masa pandemi covid-19 di Madrasah Ibtidaiyah Ngabar Ponorogo.

Penelitian ini diangkat berdasarkan penelitian terdahulu yang ditulis I Ketut Widiara yang berjudul "Blended Learning Sebagai Alternatif Pembelajaran Di Era Digital" (Widiara, 2018). Dalam penelitian ini menjelaskan mengenai alternatif pembelajaran era digital yang memadukan pembelajaran tatap muka dan online. Dari penelitian ini fokus hanya pada mengenai konsep blended learning saja, sedangkan penelitian yang dilakukan peneliti fokusnya mengenai konsep dan implementasi penilaian blended learning pada aspek keterampilan di masa pandemi covid-19.

Oleh karena itu Tujuan dari penelitian ini adalah untuk mengetahui bagaimana implementasi dari teknik penilaian aspek keterampilan dengan dua pola sistem pembelajaran daring dan luring atau dapat diartikan blended learning pada pelajaran fiqih di masa pandemi covid-19 di MI ngabar Ponorogo.

\section{METODE PENELITIAN}

Penelitian terkait implementasi teknik penilaian blended learning pada pembelajaran Fiqih masa pandemi covid-19 ini mengunakan jenis pendekatan kualitatif. Sebab metode kualitatif merupakan pegumpulan data pada latar alamiah dengan tujuan menafsirkan fenomena yang terjadi, dan kemudian dianalisis serta di interpretasikan (Anggito Albi et al, 2018).

Alasan peneliti mengunakan pendekatan dan jenis penelitian kualitatif sebab dalam pengumpulan data menerapkan teknik wawancara, dan dokumentasi. Di sisi lain penelitian kualitatif lebih bersifat ekspolarasi sehingga 
dalam mengetahui implementasi teknik penilaian blended learning aspek ketrampilan pembelajaran fiqih di masa pandemi di Madrasah Ibtidaiyah Mambaul Huda Ngabar Ponorogo.

Adapun lokasi penelitian bertempat di Madrasah Ibtidaiyah Ngabar Siman Ponorogo Jawa Timur. Teknik pengumpulan data pada penelitian mengunakan wawancara dengan guru fiqih Madrasah Ibtidaiyah Ngabar yang bernama Ustdz Ahmad Daroini, S.Pd dan dokumentasi untuk mendapatkan data pendukung seperti hasil produk atau bukti pratek siswa serta dalam penelitian ini mengunakan analisis data model miles dan huberman di mulai dari menelaah seluruh data yang tersedia dari sumber, yakni wawancara mendalam dan dokumentasi kemudian di analisis melalui tiga komponen yang meliputi reduksi data, penyajian data dan pengambilan kesimpulan (Suharsaputra, 2012).

Kemudian fokus dari penelitian ini mengarah kepada implementasi dari teknik penilaian blended learning pada aspek keterampilan pada pembelajaran Fiqih di masa pandemi yang memuat terkait konsep pembelajaran yang di pakai di masa pandemi, macam-macam teknik penilaian aspek keterampilan yang digunakan guru serta kelebihan dan kekurangan dari penerapan teknik penilaian yang di pakai di Madrasah Ibtidaiyah Ngabar Ponorogo.

\section{TEMUAN DAN PEMBAHASAN}

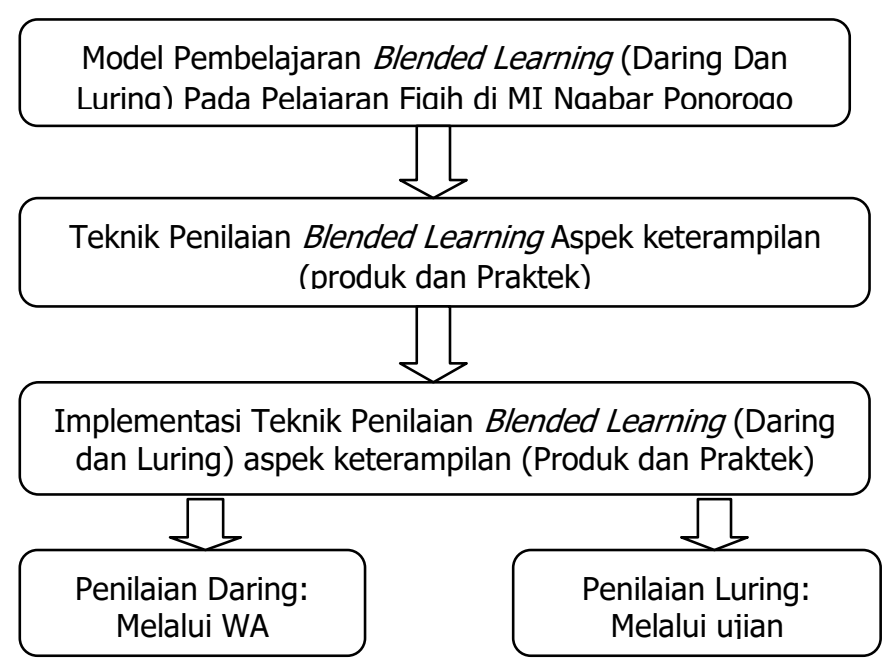

Gambar 1. Skema konsep dan penerapan penilaian blended learning aspek keterampilan di MI Ngabar Ponorogo 


\section{Konsep Pembelajaran Fiqih pada Masa Pandemi Covid-19}

Madrasah Ibtidaiyah Ngabar Ponorogo yang beralamatkan Jalan Sunan Kalijaga Nomor 9 Desa Ngabar Kecamatan Siman Kabupaten Ponorogo merupakan satu satu nya Madrasah Ibtidaiyah di Desa Ngabar. Dampak dari masa pandemi madrasah ini mengambil kebijakan dalam pelaksanaan pembelajaran mengunakan konsep blended learning atau kombinasi sistem daring dan luring.

Konsep pembelajaran blended learning merupakan model pelaksanaan pembelajaran yang dilakukan madrasah Ibtidaiyah Ngabar di masa pandemi covid 19 sebagai respon supaya pendidikan tetap dijalankan guna mencapai sebuah tujuan pendidikan nasional. Istilah blended learning merupakan kombinasi pembelajaran daring dan luring muncul karena dampak transpormasi pola pembelajaran di era digital atau era teknologi informasi seperti sekarang serta dampak dari masa pandemi covid 19 (Nasution et al., 2019).

Daring berasal dari singkatan "dalam jaringan" sebagai pengganti istilah online sebab berkaitan dengan teknologi internet atau menyambung jaringan internet. Sedangkan luring kepanjangan dari "luar jaringan" sebagai istilah offline sebab luring merupakan lawan kata daring (Ambarita, Jarwati, \& Kurnia, 2020). Jadi dapat dipahami konsep pembelajaran daring merupakan pola pembelajaran yang memerlukan sebuah penghubung atau jaringan internet, sedangakan konsep pembelajaran luring ialah pola pembelajaran yang tidak membutuhkan akses internet.

Adapun teknis pembagian penentuan siswa yang daring dari rumah dan luring di madrasah diambil berdasarkan tempat tinggal yang jauh dari madrasah dan persetujuan dari wali murid atau orang tua siswa. Jadi di Madrasah Ibtidaiyah Ngabar Ponorogo bagi siswa yang bertempat tinggal jauh dari madrasah menerapkan pola pembelajaran daring, sedangkan bagi siswa yang diberikan izin orang tua dan bertempat tinggal dekat dengan sekolah melaksanakan pola pembelajaran luring. 
Berdasarkan wawancara dengan ustdz Ahmad Daroini, S. Pd selaku pengampu pelajaran fiqih kelas 6 di Madrasah Ibtidaiyah menyampaikan bahwa dalam pelaksanaan pembelajaran jumlah siswa yang mengunakan pola daring berjumlah 15 siswa, sedangkan yang luring berjumlah 30 siswa dengan konsep pembagian setiap minggu hanya 15 siswa yang di perbolehkan ke madrasah.

Dari penjelasan diatas bahwa konsep pembelajaran yang dilakukan di MI Ngabar Ponorogo menerapakan pengabungan 2 sistem pembelajaran atau yang dikenal dengan nama blended learning dengan pembagian daring bagi siswa yang berdominisi jauh dari madrasah serta luring bagi siswa yang rumahnya dekat dengan madrasah.

\section{Macam-Macam Teknik Penilaian Blended Learning Pada Keterampilan Pembelajaran Fiqih di Masa Pandemi Covid-19}

Teknik Penilaian keterampilan adalah sebuah cara penilaian yang dilakukan guru terhadap siswa dalam pembelajaran untuk mengukur capaian pembelajaran pada ranah psikomotorik atau aplikasi penerapan pengetahuan siswa dalam melaksanakan tugas sesuatu (Sutiah, 2019). Berdasarkan Peraturan Menteri Pendidikan dan Kebudayaan Republik Indonesia Nomor 23 Tahun 2016 tentang Standar Penilaian Pendidikan bahwa macam-macam Teknik Penilaian keterampilan di lakukan melalui praktik, produk, proyek, portofolio, dan teknik lain sesuai dengan kompetensi yang dinilai. Berdasarkan wawancara dengan Ustdz Ahmad Daroini, bahwa teknik penilaian blended learning aspek keterampilan yang digunakan dalam pembelajaran Fiqih kelas 6 di Madrasah Ibtidaiyah Ngabar Ponorogo mengunakan teknik penilaian produk dan teknik penilaian unjuk kerja atau pratik.

Teknik penilaian produk merupakan penilaian kemampuan peserta didik dalam pembuatan produk-produk teknologi seni dan hasil karya (Ismanto, 2014). Teknik ini dalam pelaksanaan nya di gunakan untuk membuat sebuah kliping mengenai materi fiqih tentang binatang halal. Adapun hasil produk kliping sebagai berikut: 


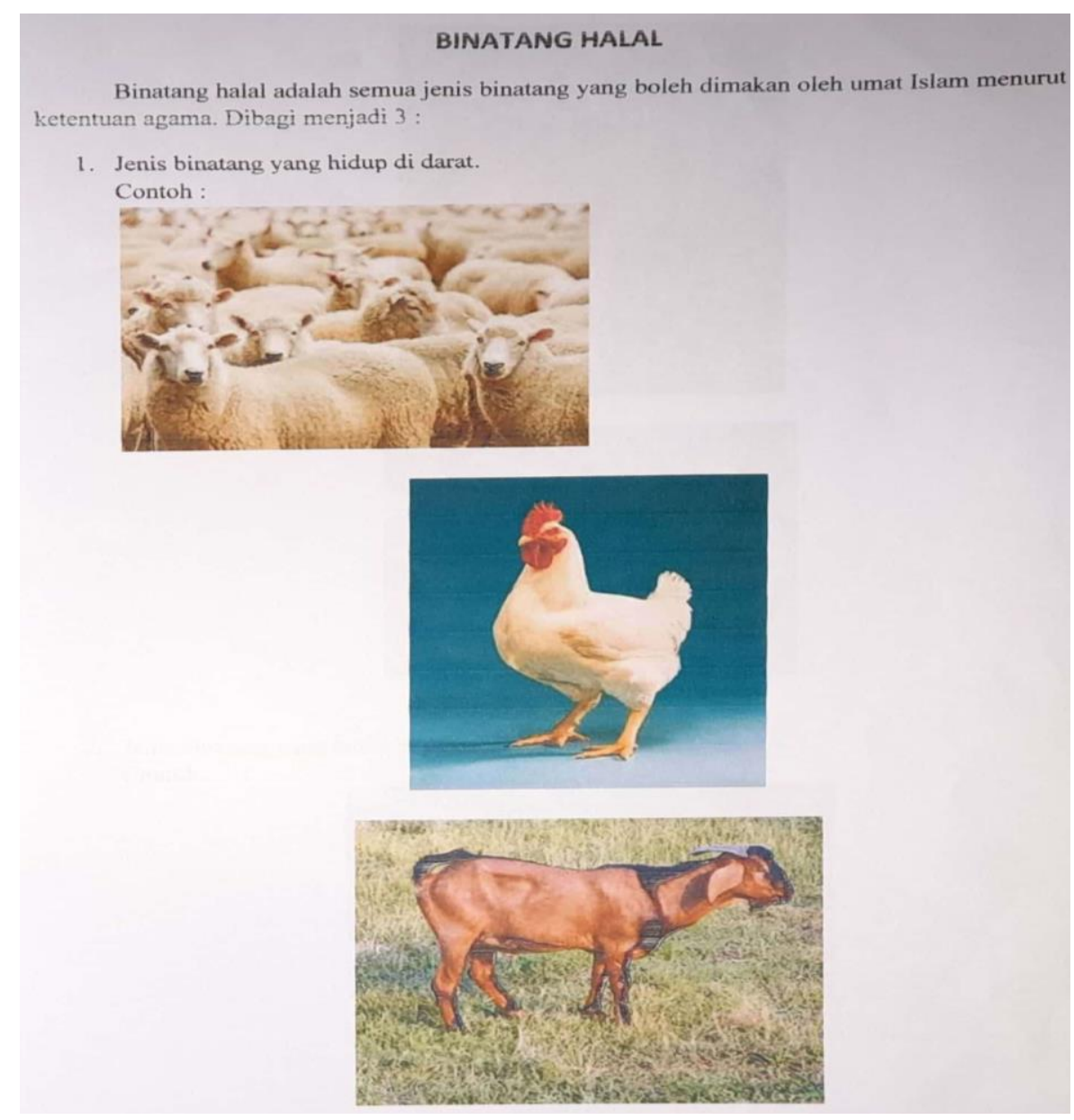

Gambar 1. Hasil karya kliping tentang materi fikih binatang halal boleh dimakan

Sedangkan teknik penilaian unjuk kerja atau praktik yaitu penilaian yang dilakukan dengan mengamati kegiatan peserta didik dalam melakukan sesuatu (Ulpah, Amaliyah, \& Yusuf, 2016). Teknik ini digunakan untuk mengetahui pemahaman sesungguhnya dari siswa dari materi yang telah disampaikan oleh guru. Adapun dokumentasi penerapan teknik unjuk kerja atau praktek sholat yang dilakukan oleh siswa: 


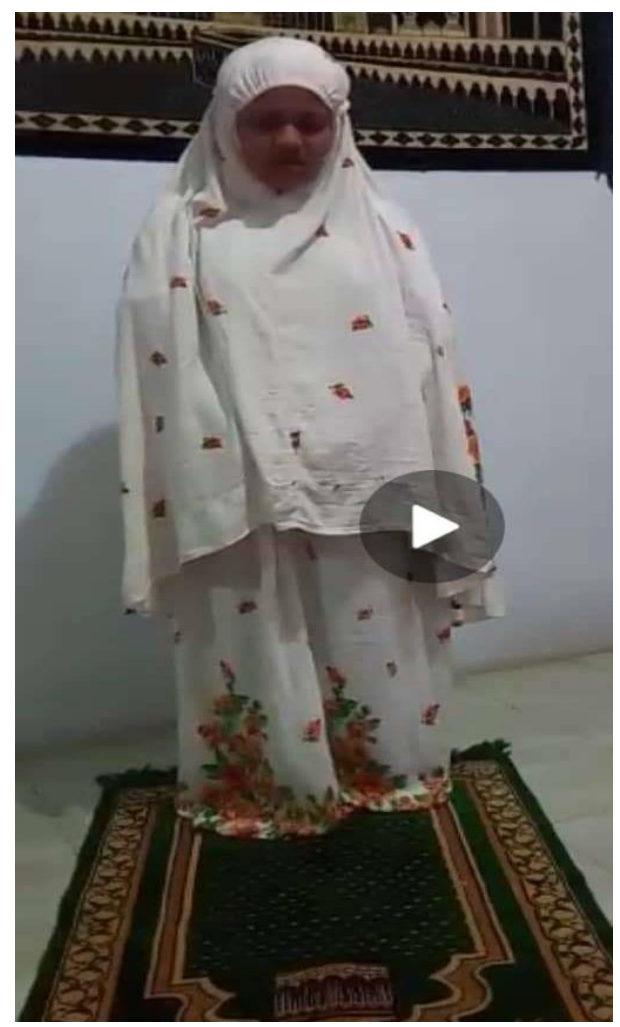

Gambar 2. Praktek sholat subuh yang dilakukan oleh siswa melalui daring

Jadi sangat terlibat jelas bahwa guru fiqih kelas 6 MI Ngabar berusaha semaksimal mungkin dalam melaksanakan teknik penilaian blended learning aspek keterampilan walaupun hanya 2 teknik yang digunakan dalam penilaian dalam pembelajaran di masa pandemi.

\section{Implementasi Teknik Penilaian Blended Learning Pada Keterampilan Pembelajaran Fiqih Masa Pandemi Covid-19}

Berdasarkan hasil wawancara dengan Ustdz Ahmad Daroini S.Pd bahwa penerapan teknik penilaian blended learning aspek keterampilan pembelajaran fiqih pada masa pandemi di Madrasah Ibtidaiyah Ngabar Ponorogo menyesuaikan konsep pembelajaran siswa yang di pilih. Teknik penilaian keterampilan siswa yang mengunakan pola pembelajaran daring teknis penilaiannyaa melihat hasil vidio praktek dan kliping melalui media whatshapp, sedangkan siswa yang mengunakan pola pembelajaran luring teknik penilaian secara langsung di nilai oleh guru baik praktek sholat subuh beserta hasil 
produk kliping siswa. Adapun format penilaian keterampilan menyesuaikan materi yang di ajarkan. Dalam hal ini contoh yang dijelaskan oleh ustdz Ahmad Daroini S.Pd mengenai materi binatang halal boleh dimakan dan praktek sholat subuh. Adapun format penilaiannya produk kliping mengenai identifikasi binatang halal dimakan sebagai berikut:

Tabel 1. Format penilaian produk pada keterampilan

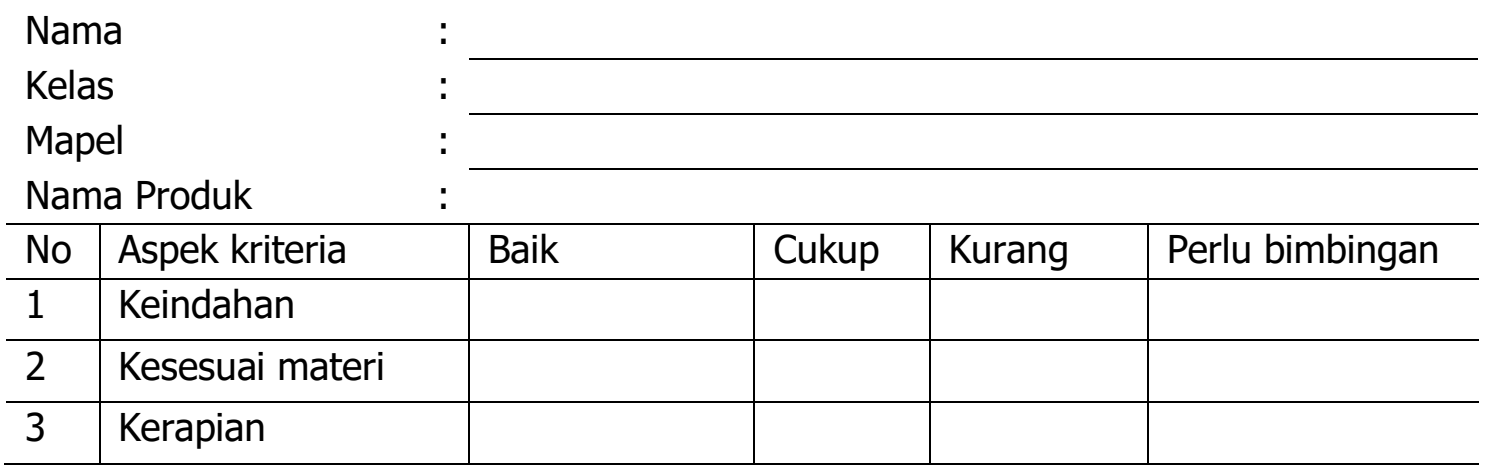

Sedangkan format penilaian unjuk kerja atau praktik mengenai sholat subuh sebagai berikut:

Tabel 2. Format Penilaian unjuk kerja atau praktik aspek keterampilan

\begin{tabular}{l|l|l|l|l|l} 
Nama & $:$ \\
Kelas & $:$ & \multicolumn{5}{l}{} \\
Mapel & $:$ & \multicolumn{5}{l}{} \\
Jenis Praktik & $:$ & Baik & Cukup & Kurang & Perlu bimbingan \\
\hline No & Aspek kriteria & & & & \\
\hline 1 & Kebenaran bacaan & & & & \\
\hline 2 & Kebenaran Gerakan sholat & & & \\
\hline 3 & Kesesuaian bacaan dan gerakan & & & & \\
\hline
\end{tabular}

\section{Kelebihan Dan Kekurangan Teknik Penilaian Blended Learning Pada Keterampilan Pembelajaran Fiqih Masa Pandemi Covid-19}

Menurut ustdz Ahmad Daroini, S.Pd menjelaskan bahwa dalam implementasi teknik penilaian blended learning pada pembelajaran fiqih di MI Ngabar Ponorogo dalam masa pandemi covid-19 terdapat kelebihan dan kurangannya. Model pembelajaran daring dengan teknik penilaian produk dan unjuk kerja atau praktik aspek keterampilan, di antaranya: melatih siswa dalam 
pemanfaatan teknologi dalam proses pembelajaran, hasil produk dan pratek siswa menjadi arsip digital, teknik yang tidak membebani siswa pada masa pandemi sebab pembuatan produk dan praktek cukup di rumah saja. sedangkan kekurangannya, terkendala jaringan bagi siswa yang tidak memiliki paket data atau susah sinyal sebab pengumpulan hasil praktek dan produk di laporkan via whatshapp, penilaian guru kurang maksimal sebab hanya melihat hasil produk dan praktek siswa via whatshapp.

Kemudian kelebihan model pembelajaran luring dengan kedua teknik tersebut yaitu produk dan unjuk kerja atau praktek pada ranah keterampilan,yakni: guru dapat mengarahkan siswa jika terjadi kesalahan praktek atau hasil produk secara langsung, sedangkan kekurangnya yakni siswa kurang paham teknologi, membutuhkan waktu yang terikat sebab antara guru dan murid harus bersamaan hadirnya.

\section{KESIMPULAN}

Pelaksanaan pembelajaran fiqih di madrasah ibtidaiyah ngabar Ponorogo pada masa pandemi mengunakan konsep blended learning atau familiar disebut sistem daring dan luring. Adapun teknik penilaian blended learning aspek keterampilan yang digunakan teknik penilaian produk dan teknik penilaian praktek. Kemudian kelebihan dari teknik penilain produk dan teknik penilaian praktek bagi siswa yang mengunakan sistem daring dapat mengunakan Informasi teknologi modern, hasil produk dan praktek menjadi arsip digital, tidak mengharuskan siswa keluar rumah, sedangkan Kekurangannya jika terdapat kesalahan dalam praktek tidak bisa langsung dibenarkan oleh guru, penilaian guru kurang maksimal, tidak dapat melaksanakan praktek dan mengiriman produk disebabkan susah jaringan dan tidak memiliki paket data. pembelajaran Luring mengunakan kedua teknik penilaian tersebut kelebihannya apabila terjadi kesalahan praktek bisa langsung dibetulkan langsung dari guru, sedangkan Kekurangannya gaptek dalam informasi teknologi, dan mengharuskan siswa dan guru hadir bersamaan. 
Rekomendasi kedepannya bagi peneliti selanjutnya alangkah baiknya dapat membandingkan antara teknik penilaian blended learning aspek keterampilan di Madrasah dengan sekolah umum agar mendapatkan data yang lebih lengkap dan keduanya dapat dijadikan pembanding serta menjadi evaluasi bagi guru, sekolah/madrasah dan pemerintah.

\section{BIBLIOGRAFI}

[1] Ambarita, J., Jarwati, R., \& Kurnia, D. (2020). Pembelajaran Luring. Indramayu: Adab.

[2] Anggito Albi et al. (2018). Metodologi Penelitian Kuantitatif. Sukabumi: Cv Jejak.

[3] Ikhwan, A. (2013). Pengembangan Kurikulum Pendidikan Agama Islam (PAI). Malang: Insan Cita Press dan STAIM Tulungagung.

[4] Ikhwan, A., Anwar, S., \& Mahmudah, N. (2021). Tahsin and Tahfidz Learning System at Integrated Islamic Elementary School (SDIT) Insan Madani During the Pandemic Covid-19. Al-Hayat: Journal of Islamic Education (AJIE), 4(2), 1-11.

[5] Ismanto. (2014). Evaluasi Hasil Belajar Pendidikan Agama Islam (PAI). Edukasia: Jurnal Penelitian Pendidikan Islam, 9 (2).

[6] Karim, C., \& Abdul, A. (2015). Pengaruh Penilaian Keterampilan Mata Pelajaran PPKN Dalam Kurikulum 2013 Terhadap Pembinaan Tanggung Jawab Warga Negara (Civic Responsibility) Di SMK Negeri Se-Kota Bandung. Mimbar Demokrasi, 15 (1), 88-108.

[7] Menteri Pendidikan dan Kebudayaan RI. (2016). Peraturan Menteri Pendidikan Dan Kebudayaan Republik Indonesia Nomor 23 Tahun 2016 Tentang Standar Penilaian Pendidikan Bab II Mengenai Lingkup Penilaian Pasal 3 Ayat 4.

[8] Nasution, N., Jalinus, N., \& Syahril. (2019). Buku Model Blended Learning. (B. Simamora, Ed.) (pertama). Padang: Unilak Press.

[9] Purwanto, M. N. (2011). IImu Pendidikan Teoritis Dan Praktis. Bandung: Remaja Rosdakarya Offset.

[10] Suharsaputra, U. (2012). Metodologi Peneliti:Kuantitatif, Kualitatif, Dan Tindakan. Bandung: Pt Refika Aditama. 
[11] Sutiah. (2019). Budaya Belajar dan Inovasi Pembelajaran PAI. Sidoarjo: Nizamia Learning Center.

[12] Ulpah, S., Amaliyah, \& Yusuf, I. (2016). Kemampuan Guru PAI Dalam Merencanakan Dan Melaksanakan Penilaian Autentik. Studi Al-Qur'an; Membangun Tradisi Berfikir Qur'ani, 12 (2).

[13] Wachyudi, A. (2020). Peran Dan Tantangan Pendidikan Agama Islam Di Era Pandemi Covid 19 Pada Lingkungan Keluarga. Journal Of Islamic Education, 5 (2), 170.

[14] Widiara, I. K. (2018). Blended Learning Sebagai Alternatif Pembelajaran Di Era Digital. Purwadita, 2 (2), 50-56. 